\title{
THE ABSENCE OF MOTHER: THE RELATIONSHIP OF FATHER DAUGHTER IN GOTHIC FICTIONS
}

\author{
Hujuala Rika Ayu \\ English Literature, FBS, Universitas Negeri Surabaya \\ hujualarika@unesa.ac.id
}

\begin{abstract}
This paper discusses the bonding of father and daughter in Angela Carter's "The Courtship of Mr. Lyon" and Intan Paramaditha's "Pintu Merah" (transl. "The Red Door"). Carter and Paramaditha employ distinguished narrative structures to highlight the interaction among the characters. They utilizes third-person narrator and reproduces fairy tales. The absence of mother becomes an interesting pivot in both stories. In that situation, father is inevitably the daughter's closest figure. In both stories, fathers are at the same time demanding and lame. While, daughters are those dependent, submissive yet tactical figures in facing their fathers as the sole counterparts in the story. Using the perspectives of Juliett Michelle and Nancy Chodorow on psychoanalysis feminism, this paper unveils the roles of father in daughter's adolescent development. This study reveals that despite the dependencies of the daughters toward the familial relationship, they use their submissiveness as the weapons to break the patriarchal values represented by the fathers.
\end{abstract}

Keywords: Gothic fiction, psychoanalysis feminism, fairy tale, father daughter relationship

\section{INTRODUCTION}

The bonding of parents and children possesses significant meaning in the construction of a family. It, in fact, is a stepping stone in which human civilization firstly created. Family have pivotal roles in the development of children. Coppelia Kahn states that "From being mothered and fathered, we learn to be ourselves as men and women." (1986, p.241). The figure of father and mother are both equally important in children development. They are the first resource from which children learn human bonding. Their parents are their role modelling. Parentschildren bonding is particularly important in children's self-identification process. In this smallest construction of society, societal and gender roles are infiltrated 
through norms and values. Children - boys and girls, sons and daughters learn and understand their roles before they eventually merge into a larger society.

Psychoanalysis provides a comprehensive elaboration on the importance of family bonding. According to Tyson, "family is very important in psychoanalytic theory because we are each a product of the role we are given in the familycomplex (2006, p.13). The relationship between parents and children as well as among siblings determine the characteristics of children. However, Juliett Michell, underlines in Psychoanalysis and Feminism: A Radical Reassessment of Freudian Analysis that it is not 'family' that contribute fundamentally in shaping the society but it is more the structural relationship between families that differentiates human or people from primate (2000, p.374). Michell sees family in a larger scope that can create a wider network that further becomes the typical of human.

Family as the smallest embodiment of society has sets of laws that innately settle the hierarchy of the family members. This sets of laws encompasses the roles of the family member. It inevitably resolves the power relations within the familial structure. The power relations further exerts the patriarchal system. Hierarchically, father is the first figure and mother is the second in the family. Father, as the ruler in family, may have distinguished position. In a patrilineal society, father is the patriarchal agent and the center of the family (Michell, 2000, p.394). Father sets the familial rules and norms. Father deals with the outer matters and mother is in charge with the domestic sites. Although nurturing children is shared duties between father and mother, mother is instinctively given the roles of nurturing and caring the children. Handojo and Djunjung assert that "the society's discourse also accepts as true that taking care of the children is the main responsibility of a woman" (2016, p.25). Being a woman and a mother is permanently related to the term motherhood. Fatherhood, however, as a term is 
not as common as motherhood and the term itself may suggest different meaning (ibid).

This paper discusses the works of two female gothic writers, Angela Carter and Intan Paramaditha. These female writers have different backgrounds. Angela Carter and Intan Paramaditha are both well known of their capacity as gothic fiction writers. Angela Carter was British gothic writer while Intan Paramaditha is a young contemporary Indonesian writer. Although Intan does not declare herself a gothic fiction writer, her short stories filled with the stories of monster or other strange creatures. Carter and Paramaditha have something in common. They employ a conventional story line that blends the adaptation of the classic fairy tales and modern women's stories in order to enrich their stories and strengthen the characters.

"The Courtship of Mr. Lyon" follows the story line of the famous Beauty and the Beast. It employs a traditional plot in which parents are dominant and intervene man woman relationship. Beauty, the female character in the story is handed over by her father to an ugly monstrous male, Beast as a substitute of his life. The relationship is meant to test Beauty's truly love to Beast. Beauty, in fact, has the power to alter Beast. Meanwhile, "The Red Door" apparently follows Brother Grimm's The Little Red Riding Hood. The protagonist, Dahlia, is the little red in "The Red Door".

Similarly, Dahlia is confronted with the animal character, wolf and the old woman in the story. Dahlia lives alone with her father. She is the youngest and 'handed over' by her siblings to the father, the commanding figure in the family. She is given responsible to take care the father. Their stories are mostly filled with the figures of the mysterious creatures such as monsters, beasts as well as wild animals like wolf. Ghosts and the haunting places are usually chosen as the space or setting of gothic stories. Gothic fiction, as a genre, has qualifications that distinguished it from other genre. Gothic fiction usually takes place in:

30 | http://journal.unesa.ac.id/index.php/paramasastra 
"an antiquated space - be it a castle, a foreign palace, an abbey, a vast prison, a subterranean crypt, a graveyard, a primeval frontier or island, a large old house or theatre, an aging city or urban underworld, a decaying storehouse, factory, laboratory, public building, or some new recreation of an older venue, such as an office with old filing cabinets, an overworked spaceship, or a computer memory." (Hogle, 2002, p.2).

Spaces, indeed, play a pivotal role in the psychological development of the main characters in gothic fiction. The haunting spaces are the residences of evil, monsters, and animals. These mysterious creatures are the embodiments of the past that re-emerge and haunt the main character's life in the story. "The Courtship of Mr. Lyon" and "The Red Door" are situated in a remote, dark and vague spaces. "The Courtship of Mr. Lyon" is set mostly in a Palladian house in which the Beast lives which later Beauty also stays in there. While, Dahlia and her father in "The Red Door" lives in an "old house during Dutch's occupation with faded classical tiles, big storeroom and deep well" (Paramaditha, 2000, p.51). The mysterious creature in "The Courtship of Mr. Lyon" is the beast. "The Red Door" is filled with wolves and the figure of old woman.

This paper explores the relationship of father and daughter in "The Courtship of Mr. Lyon" and "The Red Door" particularly in terms of the roles of father in shaping the daughters' development. The absence of mothers in the stories are conspicuous aspects that stresses the inevitable relationship between father and daughter. This study uses the perspectives of Juliett Michelle and Nancy Chodorow on psychoanalysis feminism. Michelle and Chodorow foreground their concepts on the former eminent theorists of psychoanalysis, Sigmund Freud and Jacques Lacan.

\section{DISCUSSION}


Angela Carter's "The Courtship of Mr. Lyon" was firstly published in the short stories collection, The Bloody Chamber and Other Adult Tales, in 1979. Most stories in The Bloody Chamber and Other Adult Tales are basically adapted from traditional fairy tales such as "Bluebeard", "Beauty and the Beast", "Puss in Boots", and "Little Red Riding Hood". The words, 'adult tales' indicate the sense of 'pornographic' and the categorization of the book, to whom the book is essentially addressed to. Indeed, Carter's stories were 'pornographic' as they explore man-woman relationship which "constitutes an important part of the contemporary discourse on sexuality" (Sheets, 1991, p.633).

The second short story, Intan Paramaditha's "Pintu Merah" (Transl. "The Red Door") was initially published in Koran Tempo in 2005. "The Red Door" was then included into her short story collection, Sihir Perempuan and published in the same year. During the celebration of women's body by sastrawan wangi Indonesia, Sihir Perempuan offers another perspectives of women stories. It does not only explore women's body but also employ fairy tales and ghost stories to reveal women's fight against patriarchy. Kurnianto asserts, the figures of ghost in Paramaditha's story does not only add that sense of magical and haunted things into the stories but also functions to break the myth or discourse constructed by the patriarchal society (2016, pp. 89-90). The appearance of ghosts qualifies their works into gothic fiction. Beauty and Dahlia, the female character in both short stories have something in common. Both female characters live with their father. They are motherless and father are inevitably the 'closest' figure in the family. Their world are dominantly encircled by masculinities, father and their male counterparts.

Beauty and Dahlia experience distinguished situation. The situation may influence their physical and psychological sides. This differing situation are parts of the important aspect in gothic fiction. In terms of gothic situation, Hogle differentiates this aspect of gothic fiction as "terror gothic" and "horror gothic" 
(2002, p.3). Terror gothic (fiction) presents fearful climax either to the readers or characters that threat the main character's life, sanity and safety. Horror gothic (fiction), on the other hand, exposes the reader or the principal character with vulgar and violent of physical and psychological ending. It usually breaks the daily norm with dreadful results (Ibid). "The Courtship of Mr. Lyon" can be put into terror gothic as its principal character, Beauty does not feel safe in her relationship with the antagonist, The Beast. However, the story does not result in sarcastic ending. In contrast, “The Red Door” shows a minor 'bloody' ending. The emergence of old woman taking Dahlia away into the well can be an example of why this story is sorted into horror gothic. Dahlia's curiosity kills her as she enters into the red door. Dahlia's 'bloody' action carries consequences as she breaks the realm behind the red door.

The familial structure in "The Courtship of Mr. Lyon" comprises the character father and Beauty. The figure of mother and siblings are nonexistent in the story. "The Red Door" shows the familial structure of father and daughter. Siblings are present. "The Courtship of Mr. Lyon" begins with Beauty set in the kitchen doing her chores. The initial setting, the kitchen, is described as "mean kitchen" (Carter, 1993, p.50) as to represent Beauty's situation of being alone and neglected. The kitchen seems to contrast the physical appearance of Beauty who is analogized as "made all of snow" (ibid).

"The Red Door", on the other hand, is initiated with Dahlia and the father's short conversation. The short conversation is written in italics as to separate the lines from the description of the stories.

I'm not going to go home late.

I'm ill if you go home late. I'm so ill.

Yes, Papa. I know. I'll see you, later, Pa.

(Paramaditha, 2005, p.49).

http://journal.unesa.ac.id/index.php/paramasastra | 33 
The conversation between Dahlia and her father reveals the father's dependence toward her daughter. Dahlia seems to understand her father's dependence and assures him that she is not going to go home late and be back soon. Paramaditha employs italic's way of writing in some parts of her stories. This way of writing brings the readers to the closeness. Readers may behold or feel Dahlia's sentiment more clearly. It also shows the minor characters' action or feeling toward their father. "The Courtship of Mr. Lyon" is told in the third narrative point of view. It uses the names of the characters. While "The Red Doors" is seen from the perspective of the third person by the using of the 'I'. They can be then categorized into the genre of gothic fiction as it exposes the character of beast and its haunting residence.

The settings of the stories, however, imply the manly characteristics of the male figures. "The Courtship of Mr. Lyon" dominantly takes place in the beast's residence. The residence is depicted as a "Palladian house that seemed to hide itself shyly behind snow-laden skirts of an antique cypress" (Carter, 1993, p.51). The description of the house signifies the nature of the beast. The Beast is Beauty's male counterpart. He is the binary opposition of Beauty. Beast mostly hides himself against public. He does not accept any 'human' companion in his Palladian house. His only companion is "a liver and white King Charles spaniel" (ibid). Correspondingly, "The Red Door" is situated in an antiquated Dutch era house. The house was "splendid for such a house in a small city" (Paramaditha, 2005, p.51) and typically masculine as it was inherited from the grandfather who was a respected official in the past. It represents the dictatorial grandeur of the owners as well as the fading authority of the father who was a very important person in the past.

The figures of fathers in both stories have similar qualities. Both fathers are in the transitional phase. Beauty's father is in his edge of bankruptcy. Her father is 34 | http://journal.unesa.ac.id/index.php/paramasastra 
unsuccessful with his business. He has troubles with law that later change him from someone "who had been so rich, [then] had come to be so poor" (Carter, 1993, p.56). Dahlia's papa similarly was once a commanding individual. He is then retired and ill. He is described as:

"And look how lame he is: he whose voice has ever echoed in the alley's house, he who can feel his children's vibration of lies even though they hide under the bed, he is the dictator using his iron hands in the name of love. Now he is just a retired man with his smelly grey hair who has to nap. His seventy years old heart is weak, and he is so dependent to her daughter that he has always to grip her hands" (Paramaditha, 2005, p.50).

Father and papa are described differently in terms of personality. Beauty's father seems to be gentler than Dahlia's papa. Dahlia's papa, on the other hand, is tyrannical. Mothers in both stories are absent. They passed away. Beauty seems to be the only daughter in the family. While Dahlia is the youngest and the dearest daughter of all. Adit, Rama, and Sarita are her siblings.

Although father is the second figure after mother in determining children's development, father may have distinguished roles in daughters' growth. According to Chodorow, the figure of father is most important in daughter's periods of oedipal and early adolescence (1978, p. 139). Within these periods, daughter strives with her turning process to heterosexuality. In other words, fathers' roles are pivotal in shaping daughters' femininity. Femininity, in this case is related to daughters' future roles in family, being a mother and a wife (maternal and heterosexual). Father 'feminizes' daughters. Daughters learn the roles of feminine aspects such as being passive and dependence (ibid). Beauty and Dahlia enter their phase of womanhood. Father's presence assists daughter into the period of being a heterosexual and maternal female. "The Courtship of Mr. Lyon" is started with Beauty's existence in the kitchen. Kitchen and Beauty are placed in 
the same line. The sameness seem to underscore Beauty's being as the female character and daughter whose roles as caregiver of the house and the father. Beauty substitutes the roles of mother in the house. Through the absence of the mother, Beauty inherits that sense of motherhood and learns how to be a 'wife'. She is, therefore, a daughter and a wife at the same time. Beauty's dual roles in the story, however, are problematic. She is his. She belongs to her father. In the beginning of the short story, Beauty's position to her father is emphasized as "his Beauty, his girl-child, his pet" (ibid). The word "his" is repeated three times in that sentence to expose the dominance of the father and his sense of belongingness toward the daughter. Meanwhile, the word "pet" may have ambivalent meanings. It may be positive in order to show the father's affection toward the daughter. On the other hand, the word pet may represent the power relations of father and daughter in the story. It underscores the dominant-passive relationship of father and daughter.

Both settings of places present a symmetry story line that reveals the linear familial structure of the characters. Beast and father represent the male powerful patriarchal figures in the story. They are more dominant than other characters. Beast's authority is metaphorically embedded in "the great paws [that] lying on the arm of his chair" (Carter, 1993, p.55). Paws indicate the symbols of male power showing his capacity of gripping the subordinate. The figure of father exercises his power through Beauty, as his only familial relationship. The father exchanges Beauty for the white rose which he stole from Beast. On the other hand, Beauty and the spaniel signify subordinate position in the story. They become the consoler of the house. They are loyal, submissive and obedient to their masters. Beauty has admitted that she is bounded by "the sense of obligation to an unusual degree" (ibid). She is an object either for her father and the beast as she confesses herself to be "Miss Lamb, spotless, sacrificial" (ibid). The spaniel is in line with Beauty in terms of their position as the caretaker of the house. He is the 
equilibrium of Beast. His existence in the house is to prevent Beast from "his otherness" (Carter, 1993, p.54).

Dahlia has similar destiny to Beauty. As the youngest and the dearest daughter of her Papa, her siblings to some extent agree that Dahlia has to stay and bear the duty of nurturing the Papa, the head of the family. She is prepared to be her Papa's nurse, to be the substitute of mother in the family. Her siblings seem to shut all possible doors that may lead to Dahlia's self-development such as career or making a relationship with man. In fact, Papa is keener to Dahlia than to other children. He does not choose Adit or Rama, the male children. He fails to correlate himself with the other three children, Adit, Rama and Sarita. Dahlia seems to be the most submissive child in the family. She appears to be dutiful and loyal. Although Dahlia is not as bright as her siblings, she has fulfilled her Papa's expectation. Her papa said:

"But you, my little daughter, you are the best. Even when you are a baby, you seldom cry, very obedient," he touches Dahlia's eyes as if he strokes a rabbit. (Paramaditha, 2003, p.54).

Dahlia is her Papa's compensation. She is an object of amusement that cures his disappointment toward his other children. The tyrannical Papa loses control over his three children. Lacking of control over his other three children results in his turning toward Dahlia. Like Beauty, Dahlia is a pet to her papa. She is analogized as "a rabbit", sweet and submissive. Being a seldom crying baby foreshadows Dahlia's adolescent state. Crying is considered to be an interruption, a disobedience toward the parents. Compared to her siblings, she is not a trouble maker in the family. The red door, as the title suggests, has metaphorically meaning. Red color implies the qualities the door has. It represents courage and braveness. The red door leads Dahlia to the forest, creatures and well, a journey to the unconsciousness. Dahlia's journey is so 'Alice's adventure in wonderland'. 
Going through the red door and experiencing the world in it represents Dahlia's escape from the real world, from the Papa's territory.

Within the interaction of daughter father in the stories, exchange takes significant stance. Exchange in this case means the negotiation that bears consequences particularly to the protagonists. In "The Courtship of Mr. Lyon", Beauty is exchanged to the white rose stolen by her father. In "Red Door", Dahlia is exchanged as the nurse of her father. The exchange entails multiple meanings. In the case of Beauty, exchange transforms her from a home, innocent girl into an experienced one. Moving from her father's house to the Beast's Palladian house leads her to the initial interaction with other male person other than her father. Beauty learns man-woman relationship. However, her intensive attachment with her father soon ends as he leaves her alone in Beast's house.

Next morning, her father kissed her and drove away with a renewed hope about him that made her glad, but, all the same, she longed for the shabby home of their poverty (Carter, 1993, p.55).

Beauty seems to be fragile as she finds out that she has to stay in the house with Beast. As her attachment with her father cut down, Beauty feels anxious. Daughter, in the case of the absent father, feels insecure and uneasy when they have to face men (Chodorow, 1979, p.138). Beauty feels anxious as her father leaves her with Beast. In the case of Dahlia, the exchange carries restriction. It closes chances of developing herself. Nonetheless, the exchange tests both femininity aspects of female characters. Beauty has to learn to accept the fact that she is exchanged "on some magically reciprocal scale, [for] the price of her father's good fortune" (Carter, 1993, p.55). She is obedient and passive toward her father and the Beast. She learns to be the caretakers of the male characters. In this case, although mother is the daughter's role model, the source from which she learns values and roles of being a female, father exposes her to a reality of being a female. The exchange itself is a symbolic marriage between Beast and Beauty. It 
is an 'unbalanced' match on the side of Beauty and therefore it can be called a 'primitive' marriage. It is based on the agreement of the male characters. On the side of Dahlia, being the dearest daughter results in her devoted duty as a substituted nurse as "That ex-ruler hates nurse and he only wants his dearest daughter." (Paramaditha, 2005, p.50). According to Michell, regardless of the society, whether it is a patrilineal or matrilineal, men have always been the agents of exchange. Women are the token of exchange. The exchange, however, may function as a means of communication which embrace a society (1974:410). Beauty is not only exchanged for the sake of the stolen white rose or her father's dignity and life but more than that she is "the equivalent of the sign" (Michell, 1974:370). Dahlia is exchanged by her brothers, male companion who exercise their power as male character. Nonetheless, Beauty and Dahlia have important functions in exchange. They become the bridges of the social connection between the male characters as well as diverts the exchanges into the resolution of the story. The exchange meets the characters into one closing of the story.

In dealing with the restrictive situation, the female character experience a moment of mirror stage. Mirror in fact plays a significant role in one's process of self-development. It is the medium of identification or as Lacan called it, "the dialectics of identification" (Michell, 2000, p.). This mirror stage allows one to the process of realizing herself. In one part of the short story, Beauty is facing herself on the mirror. Once she leaves Beast's Palladian house, she enjoys her life. She feels relieving of being freed from her duty as a token of exchange.

"Returning late from supper after the theatre, she took off her earrings in front of the mirror; Beauty. She smiled at herself with satisfaction. She was learning, at the end of her adolescence, how to be a spoiled child and that pearly skin of hers was plumping out, a little, with high living and compliments" (Carter, 1993, p. 59). 
Beauty seems to evaluate and admire herself. Her act of looking at her-self in front of the mirror reflects her slight of being narcissistic. Dahlia's process of realizing herself occurs as she looks at the image of a woman in the well. Dahlia calls it "my mirror" (Paramaditha, 2005, p.52). Dahlia is presented a reverse image as she gazes herself on the water. She sees the shadow of a woman there. Beauty and Dahlia go through the process of identifying herself. This process may also exerts their escape from realities.

\section{CONCLUSION}

This paper discusses the close relationship of father daughter in gothic fictions. It also sees the important roles of father in constructing daughter's selfdevelopment within the absence of the figure of mother in the stories. Based on the perspectives of psychoanalysis feminism, the figure of father is somehow important in 'feminizing' the daughters and assisting them into the negotiation of heterosexuality. The absence of literal mother in the stories is basically a metaphor. It implies the daughter's movement from mother's attachment to father. Beauty and Dahlia, the two female characters in stories are in the end of their adolescence. Their relationship with the figures of father and papa take them to the realization of self-development and identification.

However, father daughter relationship carries the notion of patriarchal authority. Father is not only seen as the second or the separate person in the early development of children but also the figure of symbolic law. Father represents the natural law in the family. Daughters, as the opposite of sons in the family, are to be compliant to the fathers' law. Father and Papa may act as the representation of fatherhood in substitute of the absent mother. Father and Papa are depicted dualistically. They are simultaneously demanding and dependent to their daughters. However, the reciprocal love can be clearly seen in the relationship of 
Hujuala Rika Ayu, The Absence of mother...(hIm. 28 - 42)

Father and Beauty than Papa and Dahlia. Father is mostly depicted as a caring father to Beauty. On the other hand, Papa establishes a more authoritative relationship with Dahlia. Beauty and Dahlia are at the same time depicted as dutiful, submissive, passive and un-initiative females yet at some points they are tactical. Daughters in fact have determining positions in father daughter relationship. Their duties as the caretakers of the fathers and the substitute of mother place them in a bargaining site.

\section{REFERENCES}

Angela, Carter. 1993. The Bloody Chamber. New York: Penguin Books, USA.

Chodorow, Nancy. 1978. The Reproduction of Mothering: Psychoanalysis and the Sociology of Gender. Berkeley, Los Angeles, and London: University of California Press.

Coppelia, Kahn. 1986. "The Absent Mother in King Lear". Rewriting the Renaissance: The Discourses of Sexual Difference in Early Modern Europe.

Eds. Margaret F. Ferguson, Maureen Quilligan, and Nancy J. Vickers. Chicago: The University of Chicago.

Hagle, Jerrold E. Ed. 2002. The Cambridge Companion to Gothic Fiction. Cambridge: Cambridge University Press.

Handojo, P.F., DjunDjung, J.M. Communicating with Feminine Bodies in Mom Lit. Kata 18.1 (2016). pp.25-32.

Hogle, Jerrold. 2002. Introduction: the Gothic Fiction in Western Culture. The Cambridge Companion to Gothic Fiction. Cambridge: Cambridge University Press. pp. 1-20.

Kurnianto, Ery Agus. Resistensi Perempuan terhadap Wacana Ratu Rumah Tangga dalam Cerpen Intan Paramaditha. Atavisme 19.1 (2016). pp.88101. 
Michell, Juliet. 2000. Psychoanalisis and Feminism: A Radical Reassessment of Freudian Analysis. New York: Penguin Books.

Paramaditha, Intan. 2005. Sihir Perempuan. Depok: Kata Kita.

Sheets, Robin Ann. Pornography, Fairy Tales, and feminism: Angela Carter's "The Bloody Chamber". Journal of the History of Sexuality 1.4 (April, 1991). pp.633-657.

Tyson, Lois. 1999. Critical Theory Today: A User-Friendly Guide. New York \& London; Garland Publishing. 